\title{
REVIEW
}

\section{Endothelium-dependent contractions in hypertension}

\author{
${ }^{*, 1}$ Paul M. Vanhoutte, ${ }^{2}$ Michel Feletou \& ${ }^{3}$ Stefano Taddei
}

\author{
${ }^{1}$ Department of Pharmacology, Faculty of Medicine, University of Hong Kong, Hong Kong, China; ${ }^{2}$ Département Diabète et \\ Maladies Métaboliques, Institut de Recherches Servier, Suresnes, France and ${ }^{3}$ Dipartimento di Medicina Interna, \\ Universita degli Studi di Pisa, Pisa, Italy
}

1 Endothelial cells, under given circumstances, can initiate contraction (constriction) of the vascular smooth muscle cells that surround them. Such endothelium-dependent, acute increases in contractile tone can be due to the withdrawal of the production of nitric oxide, to the production of vasoconstrictor peptides (angiotensin II, endothelin-1), to the formation of oxygen-derived free radicals (superoxide anions) and/or the release of vasoconstrictor metabolites of arachidonic acid. The latter have been termed endothelium-derived contracting factor (EDCF) as they can contribute to moment-to-moment changes in contractile activity of the underlying vascular smooth muscle cells.

2 To judge from animal experiments, EDCF-mediated responses are exacerbated by aging, spontaneous hypertension and diabetes.

3 To judge from human studies, they contribute to the blunting of endothelium-dependent vasodilatations in aged subjects and essential hypertensive patients.

4 Since EDCF causes vasoconstriction by activation of the TP-receptors on the vascular smooth muscle cells, selective antagonists at these receptors prevent endothelium-dependent contractions, and curtail the endothelial dysfunction in hypertension and diabetes.

British Journal of Pharmacology (2005) 144, 449-458. doi:10.1038/sj.bjp.0706042

Published online 17 January 2005

Keywords: Arachidonic acid; endoperoxides; endothelin; hypertension; nitric oxide; superoxide anions; thromboxane A2; TP-receptors

\begin{abstract}
Abbreviations: AA, arachidonic acid; ACh, acetylcholine; ADMA, asymmetric dimethylarginine; ADP, adenosine diphosphate; $\mathrm{BH}$, tetrahydrobiopterin; cGMP, cyclic guanosine monophosphate; COX, cyclooxygenase; DETCA, diethyldithiocarbamic acid; DMTU, dimethylthiourea; EDCF, endothelium-derived contracting factor; EDHF, endothelium-derived hyperpolarizing factor; EDRF, endothelium-derived relaxing factor; eNOS, endothelial nitric oxide synthase; ET, endothelin; 5-HT, 5-hydroxytryptamine; LNA, nitro-L-arginine; LNMMA, L- $N^{\mathrm{G}}$ monomethyl arginine; $\mathrm{M}$, muscarinic receptor; $\mathrm{NO}$, nitric oxide; $\mathrm{P}$, purinoceptor; $\mathrm{PGH}_{2}$, endoperoxides; $\mathrm{SHR}$, spontaneously hypertensive rat; Sol GC, soluble guanylate cyclase; SR, sarcoplasmic reticulum; TP, TP-subtype (NC-IUPHAR Nomenclature) of prostaglandin receptor; WKY, Wistar-Kyoto normotensive rat
\end{abstract}

\section{Introduction}

In 1980, Furchgott \& Zawadzki (1980) reported the obligatory role of the endothelium in the relaxation of isolated arteries to acetylcholine (ACh). This pivotal discovery not only led to the unmasking of the overall important role of nitric oxide (NO) as an intercellular messenger but also to the quest for other endothelium-derived relaxing factors (EDRF), in particular endothelium-derived hyperpolarizing factor (EDHF) (Furchgott \& Vanhoutte, 1989; Lüscher \& Vanhoutte, 1990; Vanhoutte, 1993). Furthermore, it soon became obvious that in veins, under given circumstances, the endothelial cells cause contractions, rather than relaxations of the surrounding vascular smooth muscle cells (De Mey \& Vanhoutte, 1982).

*Author for correspondence at: Department of Pharmacology, Faculty of medicine, University of Hong Kong, Level 2, Laboratory Block, Faculty of Medicine Building, 21 Sassoon Road, Hong Kong, China; E-mail: vanhoutte.hku@hku.hk

The text contained within this article is from the John Vane Lecture, delivered on July 7th 2004 in Bath during the summer meeting of the British Pharmacological Society.

Published online 17 January 2005
These endothelium-dependent responses were attributed to the production of a diffusible factor(s), termed 'endotheliumderived contracting factor' (EDCF; Figure 1). This review summarizes the current knowledge on endothelium-dependent contractions. After briefly discussing the withdrawal of the release of NO or the production of vasoconstrictor peptides, it will focus on acute endothelium-dependent increases in tone of the vascular smooth muscle that involve the production of oxygen-derived free radicals and metabolites of arachidonic acid, which ultimately activate endoperoxides-thromboxane A2 receptors (TP-receptors) on vascular smooth muscle cells (Furchgott \& Vanhoutte, 1989; Lüscher \& Vanhoutte, 1990; Vanhoutte et al., 1991; Vanhoutte, 1993; 1996; 2001; Vanhoutte \& Boulanger, 1995; Katusic, 1996; Kojda \& Harrison, 1999; McIntyre et al., 1999; Cai \& Harrison, 2000). Since there is little direct experimental evidence supporting the view that acute changes in the release of vasoconstrictor peptides produced at (angiotensin II) or by (endothelin-1) endothelial cells contribute to acute endothelium-dependent contractions, this possibility will not be considered further. Likewise, the nature and role of the 


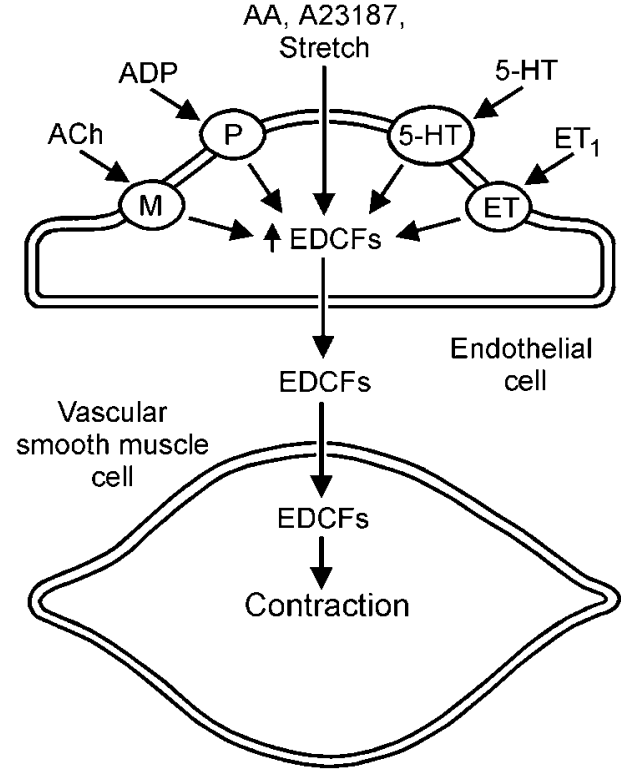

Figure 1 Under certain conditions, the endothelial cells, when activated by neurohumoral mediators, subjected to sudden stretch or exposed to the $\mathrm{Ca}^{2+}$ ionophore A23187, release a vasoconstrictor substance(s), termed endothelium-derived contracting factor $(\mathrm{EDCF}(\mathrm{s}))$, which diffuses to the underlying vascular smooth muscle and initiates its contraction. $\mathrm{AA}=$ arachidonic acid, $\mathrm{ACh}=$ acetyl choline, $\mathrm{ADP}=$ adenosine diphosphate, $\mathrm{ET}=$ endothelin, 5-HT $=5$ hydroxytryptamine, $\mathrm{M}=$ muscarinic receptor, $\mathrm{P}=$ purinoceptor, $\mathrm{O}=$ membrane receptors.

putative EDCFs released from the human umbilical vein (Saifeddine et al., 1998) or the rabbit renal artery (Streefkerk et al., 2003) will not be discussed.

\section{Animal experiments}

\section{Withdrawal of the release of $\mathrm{NO}$}

Endothelial nitric oxide synthase (eNOS; NOS III) is a constitutive enzyme, controlled by the intracellular calcium concentration. If this calcium concentration increases in response to an augmented shear stress or to endotheliumdependent vasodilators (e.g. ACh, bradykinin, catecholamines), the augmented production of NO results in greater inhibition of the underlying medial smooth muscle. As a consequence, if the latter possesses spontaneous, myogenic tone, or is exposed to vasoconstrictor signals (e.g. augmented sympathetic tone), a sudden withdrawal of the release of NO evokes acute endothelium-dependent contractions in isolated blood vessels (Figure 2; Katusic \& Vanhoutte, 1989a), or acute increases in peripheral resistance and/or arterial blood pressure in the intact organism (e.g. Rees et al., 1989). In the latter case, part of the response can be due to the withdrawal of the inhibitory effect of NO on the production of vasoconstrictor peptides, rather than that of its direct relaxing effect on vascular smooth muscle (see Vanhoutte, 2000). Possible causes of endothelium-dependent contractions due to a reduced release of NO include those caused by anoxia, particularly in arteries previously exposed to ischemiareperfusion injury (e.g. Gräser \& Vanhoutte, 1991; Pearson et al., 1996). In the intact organism, besides hypoxia (Pearson
$N^{G}$-Monomethyl-L-arginine, - $\log M$

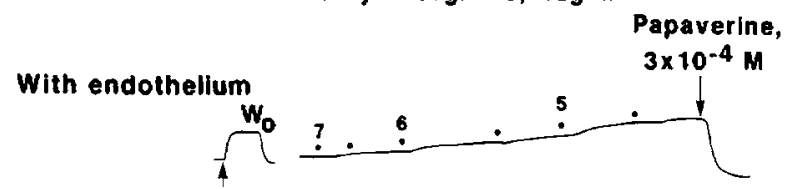

Without endothelium

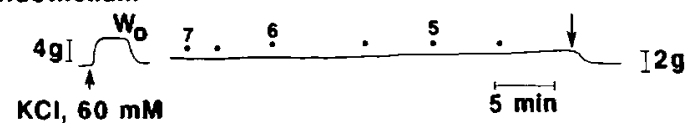

Figure 2 The arterial smooth muscle cells of the canine basilar artery possess myogenic tone, which is inhibited by basally released endothelial NO. Increasing concentrations of the NOS inhibitor $\mathrm{N}$-monomethyl-L-arginine (LNMNA) causes progressive contractions in a preparation with (upper) but only a minimal increase in tension in a ring where the endothelium has been removed (lower) (from Katusic \& Vanhoutte, 1989a; by permission of S. Karger)

\section{Pulmonary: Endothelium ortery $(0$.$) with (a)$ vein (av) withouf(ao)}

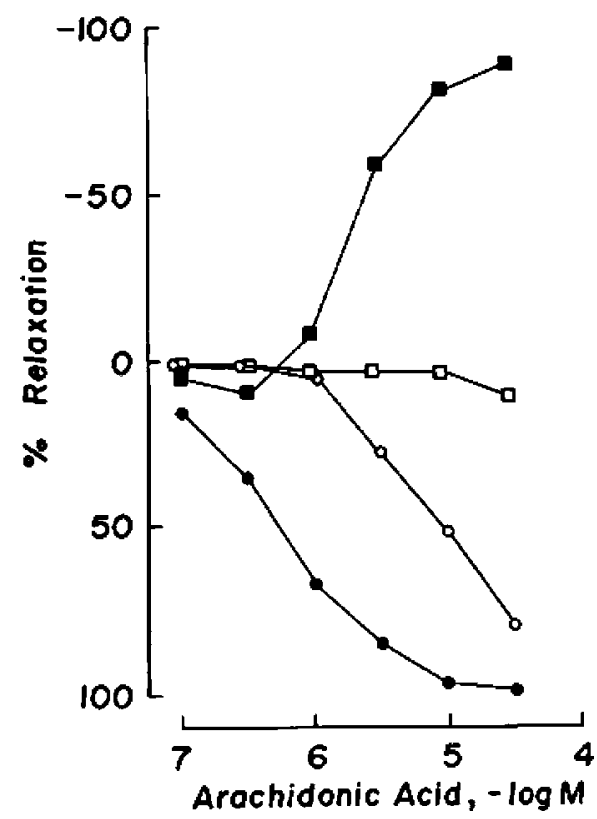

Figure 3 Effect of arachidonic acid during contractions to noradrenaline of the pulmonary artery and the pulmonary vein, with and without endothelium, of the same animal. In the former, arachidonic acid causes a relaxation that is blunted by the removal of the endothelium. In the vein, arachidonic acid causes an endothelium-dependent contraction (data from De Mey \& Vanhoutte, 1982, by permission of the AHA).

et al., 1996), they could theoretically be caused by a sudden surge in the production of endogenous inhibitors of NOS, such a asymmetric dimethyl arginine (ADMA; e.g. Vallance et al., 1992; Lin et al., 2002; Tran et al., 2003).

\section{Cyclooxygenase-dependent endothelium-dependent contractions: occurrence}

The first observations demonstrating the phenomenon of endothelium-dependent contractions were made in isolated veins of the dog (De Mey \& Vanhoutte, 1982). Thus, in these preparations, arachidonic acid and thrombin, which are 


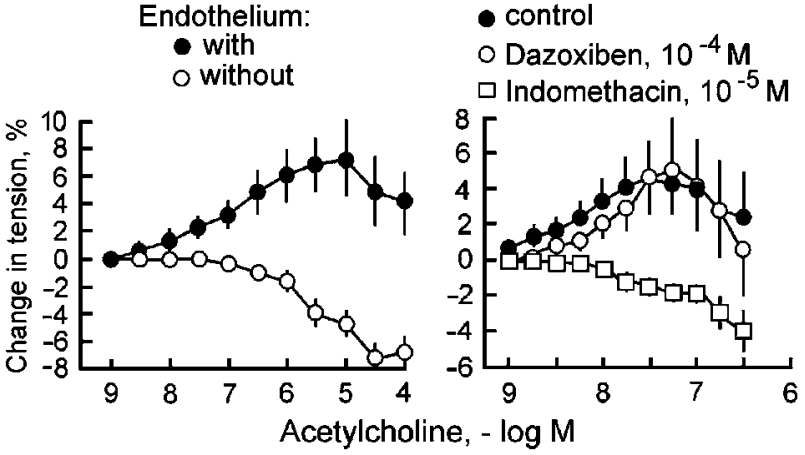

Figure 4 Left: Rings with endothelium of canine basilar arteries contract when exposed to ACh. However, the muscarinic agonist has a direct inhibitory effect on the vascular smooth muscle cells. Right: In rings with endothelium of the same artery, the endothelium-dependent contractions to $\mathrm{ACh}$ are inhibited by indomethacin (inhibitor of cyclooxygenases) not by dazoxiben (inhibitor of thromboxane synthase) (data from Katusic et al., 1988; by permission of the AHA).

\section{Spontaneously} Hypertensive Rat

Wistar-Kyoto Rat

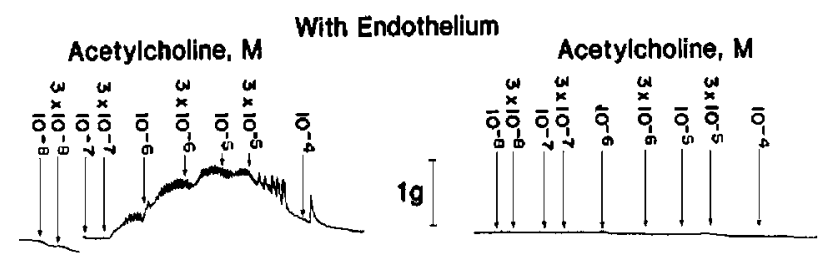

Without Endothelium
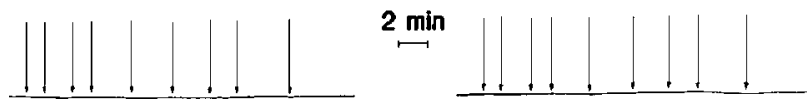

Figure 5 In rings without endothelium (lower) of SHR (left) and WKY (right) ACh has no effect. In the presence of endothelium (upper), the cholinergic transmitter induces concentration-dependent, rhythmic increases in tension only in the SHR artery (data from Lüscher \& Vanhoutte, 1986a; by permission of the AHA).

endothelium-dependent dilators in isolated arteries, potentiated, in an endothelium-dependent manner, contractions evoked by alpha1-adrenoceptor agonists (Figure 3). Similar findings have been obtained in the pulmonary artery of the male rabbit (Pfister \& Campbell, 1996). Likewise, in the quiescent basilar artery of the same species, ACh and the calcium ionophore A23187, both potent endothelium-dependent dilators in most blood vessels, evoked pronounced endothelium-dependent contractions (Figure 4, left; Katusic et al., 1988). A similar demonstration of the existence of EDCF-mediated increases in tension was made in the aorta of the spontaneously hypertensive rat (SHR; Figure 5; Lüscher \& Vanhoutte, 1986a, b; Rapoport \& Williams, 1996) and in carotid and renal arteries of hypertensive Dahl rats (Zhu et al., 1999; Zhou et al., 2001), as well as in isolated arteries of diabetic rabbits and rats (Tesfamariam et al., 1989; 1990; Chang et al., 1993; Miyata et al., 1993; Taylor et al., 1994; Keegan et al., 1995; Pieper, 1999) and in arteries of estrogen-deprived female rats (Davidge \& Zhang, 1998; Dantas et al., 1999). Thus, the concomitant reduced release of $\mathrm{NO}$ and of EDCF most likely explains the blunted endothelium-dependent relaxations to $\mathrm{ACh}$ in isolated arteries of those diseased animals.

\section{Metabolism of arachidonic acid}

In canine veins, the endothelium-dependent augmentations of the contractions to catecholamines were prevented by incubation with inhibitors of cyclooxygenase (COX) (Miller \& Vanhoutte, 1985). Likewise, inhibitors of the enzyme prevented the endothelium-dependent contractions of the canine basilar artery (Figure 4, right; Katusic et al., 1988; Miyamoto et al., 1999) and the aorta of the SHR (Lüscher \& Vanhoutte, 1986a, b; Ito et al., 1991). Indomethacin normalized endothelium-dependent relaxations in the latter preparation (Figure 6; Lüscher \& Vanhoutte, 1986a,b; Ito et al., 1991). Thus, product(s) of COX play a key role in EDCF-mediated responses. In the SHR aorta, preferential inhibitors of COX1 rather than those of COX2 prevented the endotheliumdependent contractions to ACh (Figure 7; Ge et al., 1995; Yang et al., 2002). Furthermore, the expression of COX1 was significantly greater in the aorta of adult SHRs than in that of normotensive Wistar-Kyoto (WKY) controls (Figure 8, right; Ge et al., 1995). Thus, the constitutive isoform of COX is responsible for the blunted endothelium-dependent relaxation to ACh in the SHR aorta.

In the basilar artery of the dog (Katusic et al., 1988) and in the aorta of the SHR (Lüscher \& Vanhoutte, 1986a,b), dazoxiben (an inhibitor of thromboxane synthase) does not significantly affect the indomethacin-sensitive endotheliumdependent contractions to ACh (Figure 4, right), ruling out a contribution of thromboxane A2 to the phenomenon. However, the response is prevented by antagonists at TP-receptors (Figure 9; Auch-Schwelk et al., 1990; Yang et al., 2002; 2003a,b), implying that an endogenous agonist at TPreceptors other than thromboxane $\mathrm{A} 2$ mediates the response, with the possible exception of the EDCF-mediated component

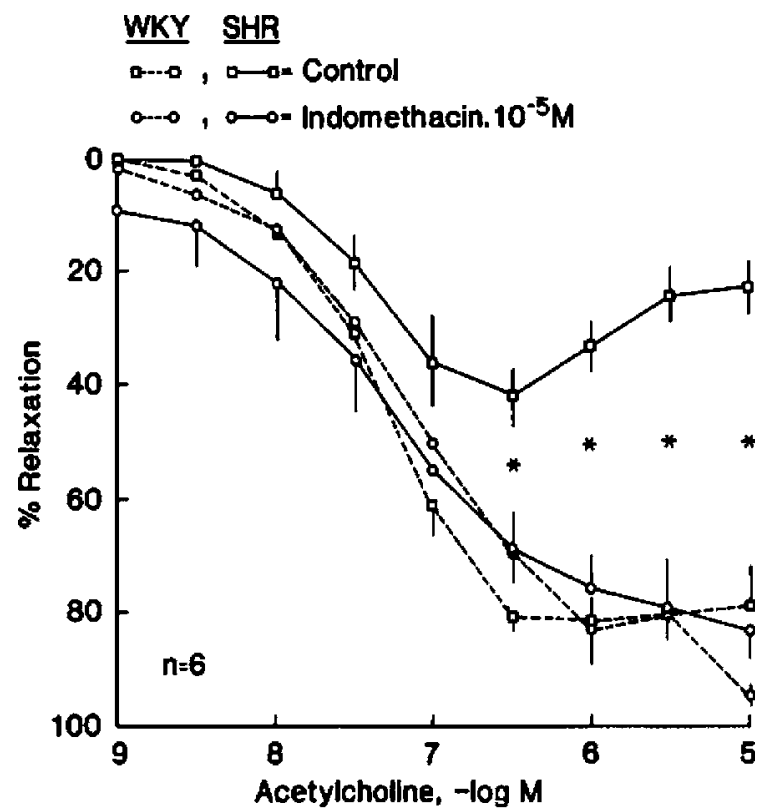

Figure 6 In contracted rings with endothelium of WKY and SHR rats, ACh causes relaxations which at higher concentrations are blunted in the arteries of the hypertensive strain. Indomethacin normalizes the response of the SHR aortas (data from Lüscher \& Vanhoutte, 1986a; by permission of the AHA). 


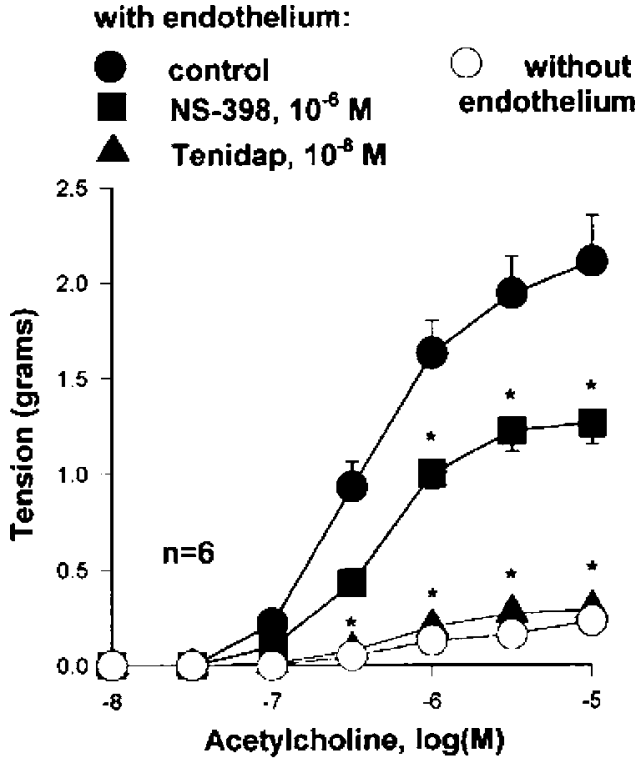

Figure 7 In aortas of 35-week old SHR (incubated with nitro-Larginine to prevent the formation of $\mathrm{NO}(36)$ ) the endotheliumdependent contraction to ACh, is minimally decreased by NS-398 (preferential $\mathrm{COX}_{2}$-inhibitor), but prevented by tenidap (preferential $\mathrm{COX}_{1}$-inhibitor) (from Ge et al., 1995; by permission of the AHA).
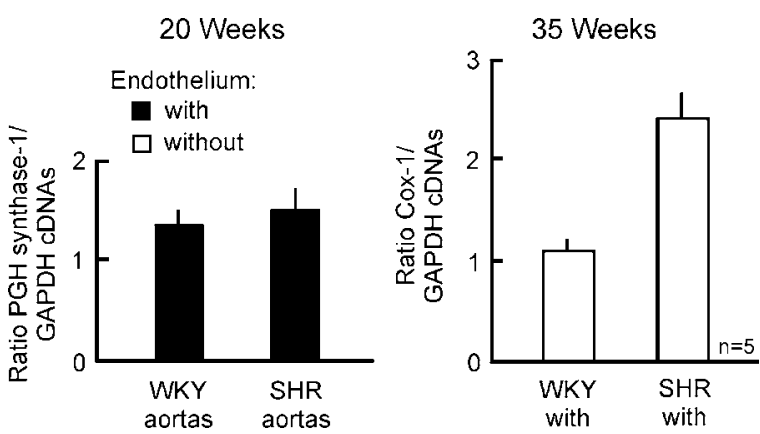

Figure 8 Prostaglandin $\mathrm{H}$ synthase $1\left(\mathrm{COX}_{1}\right)$ mRNA expression, measured by RT-PCR, in aortas with endothelium of WKY and SHR rats aged 20 (left) and 35 (right) weeks. The expression is significantly (*) augmented only in the aortas of the older rats (data from Ge et al., 1995 (by permission of the AHA) and from Ge et al., 1999 (by permission of Acta Pharmacologica Sinica)).

of the response of the SHR aorta to endothelins (Taddei \& Vanhoutte, 1993). The most likely alternative candidates are the endoperoxides, the precursors of thromboxane $\mathrm{A} 2$ that are formed by COX and also activate TP-receptors. Indeed, ACh caused a significant release of endoperoxides in the aorta of the SHR, but not in that of the WKY rat (Figure 10; Ge et al., 1995).

The comparison of the expression of COX1 in the SHR aorta yielded no significant difference between preparations with and without endothelium (Ge et al., 1995). This observation suggested that an undefined EDCF produced by the endothelial cells activates the overexpressed COX1 in the underlying vascular smooth muscle cells to produce the vasoconstrictor signal for the TP-receptors (Vanhoutte, 1996). However, this interpretation is not supported by the finding

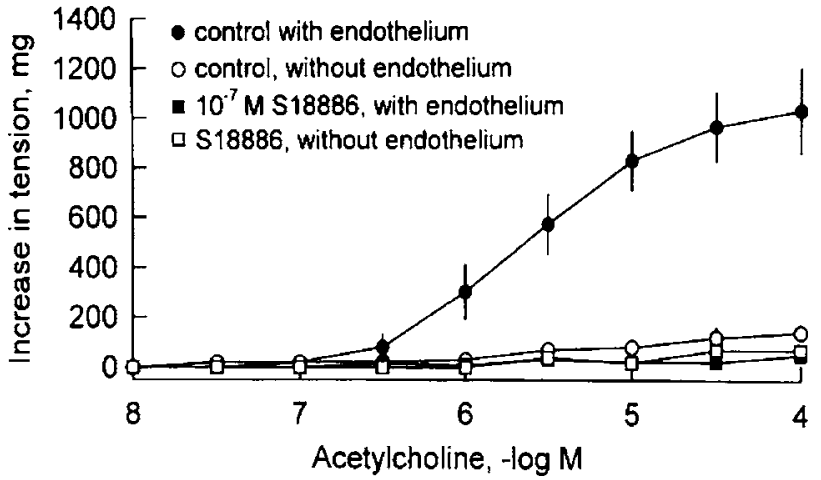

Figure 9 Endothelium-dependent contractions to ACh (in the presence of nitro-L-arginine) of the SHR aorta are abolished by S18886, a selective antagonist at TP-receptors (data from Yang et al., 2002; by permission of the British Journal of Pharmacology).

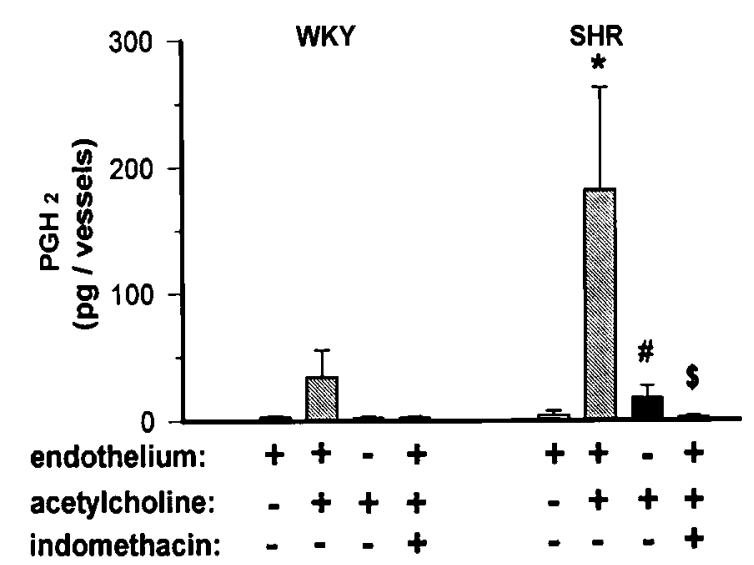

Figure 10 Release of endoperoxides $\left(\mathrm{PGH}_{2}\right)$ in aortas of WKY and SHR rats. A significant $(*)$ release of endoperoxides in response to ACh occurred only in SHR aortas with endothelium in the absence of indomethacin (data from Ge et al., 1995; by permission of the AHA).

that the augmented release of endoperoxides caused by ACh is seen only in SHR aortae with endothelium (Figure 10; Ge et al., 1995). In addition, when EDCF is bioassayed (Figure 11), COX1 inhibitors significantly decrease the endotheliumdependent contraction when given to the donor endothelial cells, but not the recipient bioassay tissue (Figure 12; Yang et al., 2003a). The same bioassay studies showed that the activation of TP-receptors on the vascular smooth muscle cells is the final event leading to endothelium-dependent contractions (Figure 13; Yang et al., 2003a). Actually, a greater than normal responsiveness to endoperoxides of these TP-receptors contributes to the occurrence of endothelium-dependent contractions to $\mathrm{ACh}$ in isolated blood vessels taken from spontaneously hypertensive animals (Figure 14, right; Ge et al., 1995).

\section{Oxygen-derived free radicals}

In the canine basilar artery, endothelium-contractions are prevented by superoxide dismutase, which dismutates superoxide anions to hydrogen peroxide, but not by catalase or 

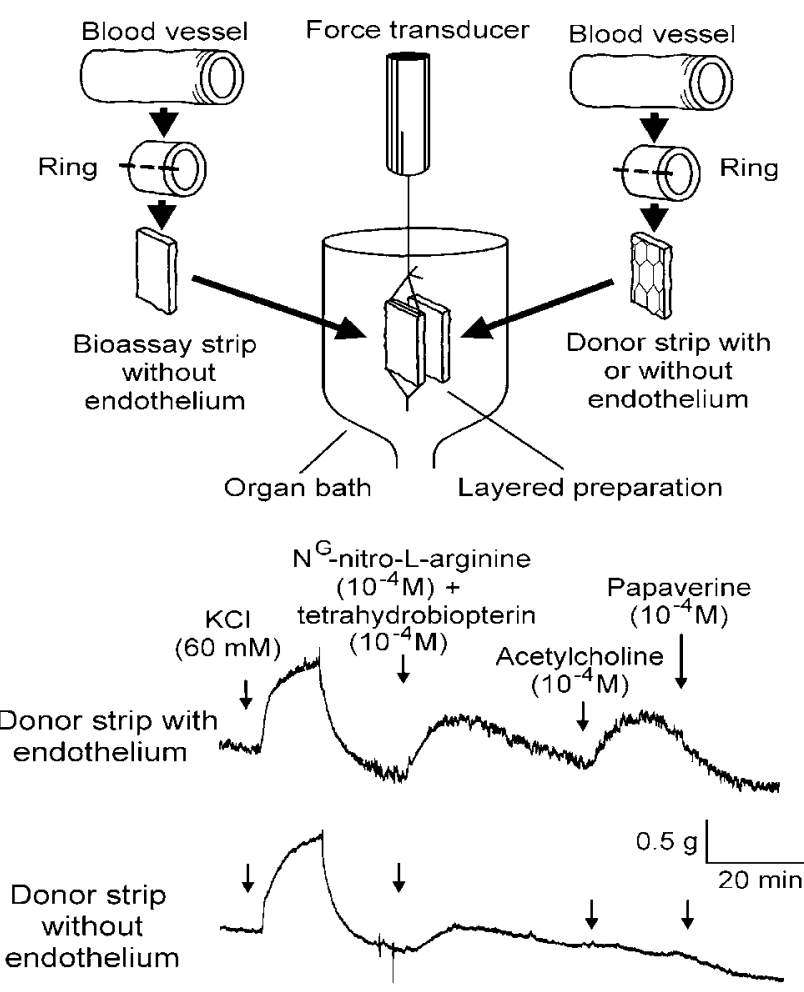

Figure 11 Top: Bioassay of EDCF. Bottom: In a layered preparation ('sandwich') of SHR aorta, ACh causes contraction only if endothelial cells are present. The experiment was performed in the presence of nitro-L-arginine (LNA) and tetrahydrobiopterin (BH4) to optimize EDCF-mediated response (data from Yang et al., 2003a; by permission of the AHA).

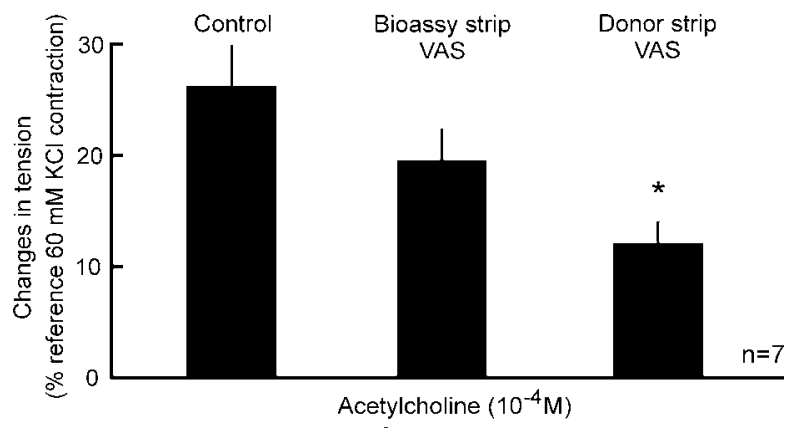

VAS $=$ valeryl salicylate $\left(3 \times 10^{-3} \mathrm{M}, 1 \mathrm{hr}\right.$ incubation, $2 \mathrm{hr}$ washout $)$

Figure 12 Demonstration of the endothelial location of the COX1 involved in EDCF-mediated contractions of the SHR aorta (data from Yang et al., 2003a; by permission of the AHA).

deferoxamine, which scavenge hydrogen peroxide and hydroxyl radicals, respectively (Katusic \& Vanhoutte, 1989b). These observations suggested an important role for superoxide anions in the phenomenon (Vanhoutte \& Katusic, 1988; Katusic \& Vanhoutte, 1989b; Cosentino et al., 1994). However, the interpretation that in canine cerebral, and other, arteries the free radical is EDCF is hard to reconcile with the extremely short physicochemical half-life of superoxide anion.

The generation of oxygen-derived free radicals in the extracellular fluid surrounding isolated aortae (without endothelium) of the SHR caused significantly larger contractions than in arteries from the WKY. Such contractions were

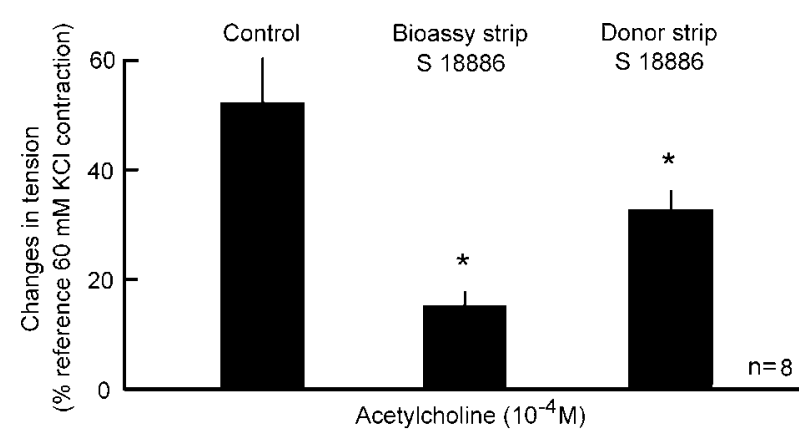

$\mathrm{S} 18886=5 \times 10^{-9} \mathrm{M}, 1 \mathrm{hr}$ incubation, $2 \mathrm{hr}$ washout

Figure 13 Bioassay demonstration of the importance of vascular smooth muscle TP-receptors in EDCF-mediated contractions of the SHR aorta (data from Yang et al., 2003a; by permission of the AHA).
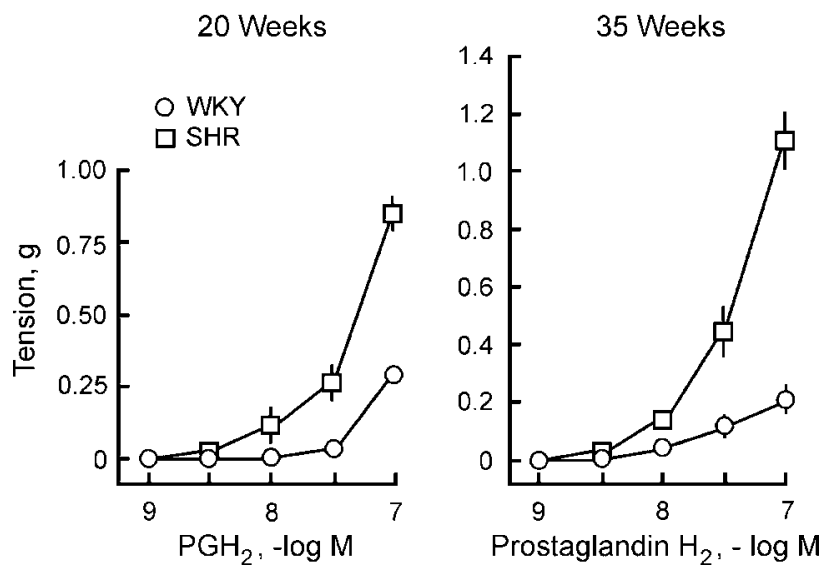

Figure 14 Contractions to endoperoxide $\left(\mathrm{PGH}_{2}\right)$ in rings (without endothelium) of aortas from 20- (left) and 35-week (right) old WKY and SHR rats. In both age groups, the responses to the endoperoxide are significantly $\left(^{*}\right)$ larger in the SHR aortas. (data from Ge et al., 1995 (by permission of the AHA) and of Ge et al., 1999 (by permission of Acta Pharmacologica Sinica)).

prevented by superoxide dismutase, indomethacin, and antagonists at TP-receptors (Auch-Schwelk et al., 1989; Rodriguez-Martinez et al., 1998). Superoxide dismutase per se does not significantly affect endothelium-dependent contractions evoked by $\mathrm{ACh}$ in intact SHR aortas. However, intracellular scavengers of the free radical inhibit endotheliumdependent contractions to ACh in the SHR aorta (Figure 15; Yang et al., 2002). Chronic in vivo depletion of oxygen-derived free radicals unmasks an inhibitory effect of superoxide dismutase on these responses (Yang et al., 2002). By contrast, in the SHR aorta, the exogenous generation of oxygen-derived free radicals potentiated endothelium-dependent contractions to ACh (Yang et al., 2003a, b). Hence, despite their extremely short half-life, superoxide anions present in the intercellular space may facilitate EDCF-mediated contractions. In blood vessels from animal models of diabetes, the involvement of oxygen-derived free radicals in endothelium-dependent contractions is also well established (Tesfamariam \& Cohen, 1992; Cosentino et al., 1996; Mayhan \& Patel, 1998; Graier et al., 1999; Shinozaki et al., 1999; Schnackenberg \& Wilcox, 2001; Zanetti et al., 2001; Nassar et al., 2002). 


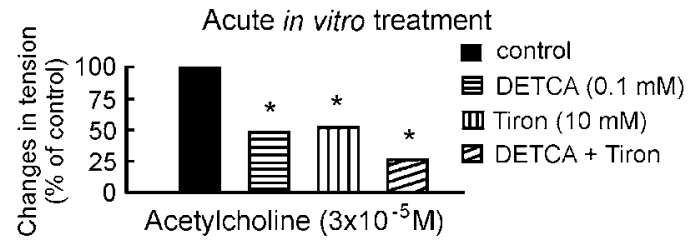

b Chronic in vivo treatment followed by acute in vitro treatment

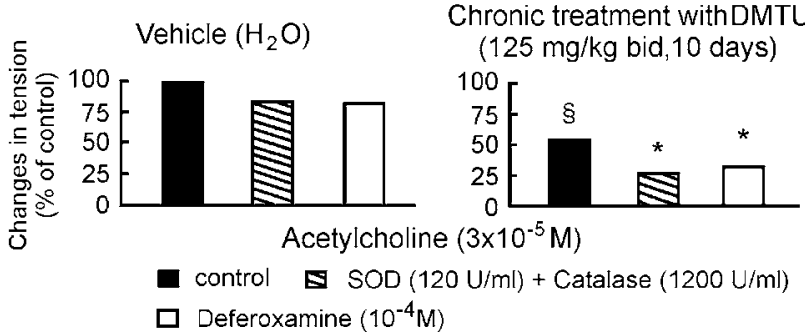

Figure 15 Upper: Effect of diethyldithiocarbamic acid (DETCA) and Tiron (intracellular scavengers of oxygen-derived free radicals) on contractions to ACh (in the presence of nitro-L-arginine; L-NA) in SHR aortas with endothelium. The scavengers were given alone or in combination. Both given alone (a and $\mathrm{b}$ ) inhibit significantly the contraction to ACh. Given together (c) they reduce it further. Lower: Effect of SOD plus catalase and of deferoxamine on endothelium-dependent contractions of aortas from control rats (left) and from animals treated chronically with dimethylthiourea (DMTU; a depletory of free radicals in vivo) (data from Yang et al., 2002; by permission of the British Journal of Pharmacology).

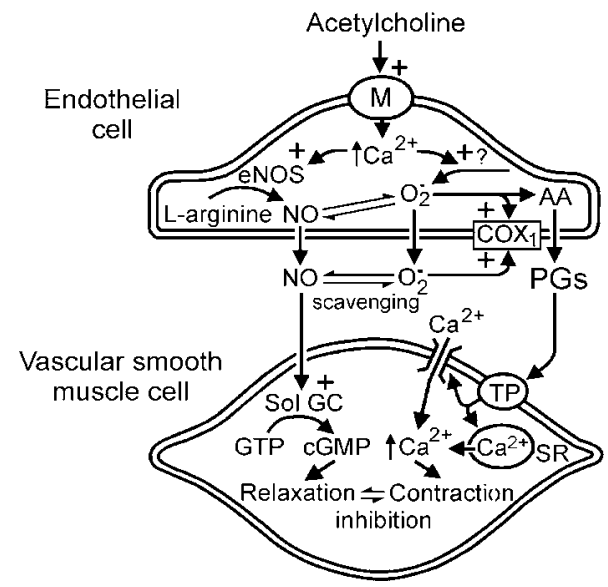

Figure 16 Schematic representations of the events leading to cyclooxygenase-dependent endothelium-dependent contractions to $\mathrm{ACh}$ in the SHR aorta. AA $=$ arachidonic acid; $\mathrm{cGMP}=$ cyclic GMP; $\quad \mathrm{COX}_{1}=$ cyclooxygenase $1 ; \mathrm{M}=$ muscarinic receptor; $\mathrm{NO}=$ nitric oxide; $\mathrm{NOS}=$ endothelial nitric oxide synthase; $\mathrm{O}_{2}=$ superoxide anions; $\mathrm{PGH}_{2}=$ endoperoxides; $\mathrm{Sol} \mathrm{GC}=$ soluble guanylate cyclase; $\mathrm{SR}=$ sarcoplasmic reticulum; $\mathrm{TP}=\mathrm{TP}$-receptors; $+=$ activation; $-=$ inhibition; $?=$ unknown site of formation

\section{Unifying concept (Figure 16)}

In arteries from spontaneously hypertensive and diabetic animals, ACh activates muscarinic receptors on the endothelial cell membrane, resulting presumably in an increased intracellular concentration of calcium, which can be mimicked by the calcium ionophore A23187, and has two consequences (Boulanger et al., 1994). The activity of eNOS increases, and more NO diffuses to the underlying vascular smooth muscle, where it stimulates soluble guanylate cyclase (Sol GC) to produce more cyclic GMP. The rise in intracellular calcium also stimulates the endothelial production of superoxide anions from an undefined source. Depending on the amount of NO, which scavenges superoxide anions (e.g. Rubanyi \& Vanhoutte, 1986), more or less superoxide anions, or its derivatives, can diffuse outside the endothelial cells. The intracellular, but maybe also extracellular superoxide anions stimulate the overexpressed, presumably membrane bound COX1 to transform arachidonic acid into endoperoxides, which diffuse to activate the hyperresponsive TP-receptors of the vascular smooth muscle. Thus, both the greater activity of COX1 and the hyper responsiveness of the TP-receptors are required for endothelium-dependent contractions (Ge et al., 1995; 1999). A reduction in the release or bioavailability of NO augments the amplitude of the endothelium-dependent contractions, as does an increased production of oxygen-derived free radicals. By contrast, scavenging or depleting superoxide anions depresses the response (Auch-Schwelk et al., 1992; Yang et al., 2002; 2003a, b).

\section{Role in health and disease}

Since in large cerebral arteries, acute distension evokes endothelium-dependent contractions, this type of response could participate in autoregulatory adjustments of the diameter in response to sudden surges in arterial blood pressure (Katusic et al., 1987). However, it is more likely that the occurrence of endothelium-dependent contractions is pathological, as they are so prominent in arteries of hypertensive and diabetic animals. In the latter case, they appear to be induced by the sustained hyperglycemia. In the spontaneous hypertensive rat, the augmented responsiveness to endoperoxides, unlike the overexpression of COX1, is already present in the aorta of prehypertensive animals (Figures 8, left and 14, left; Iwama et al., 1992; Jameson et al., 1993; Ge et al., 1995; 1999). Thus, this hyper responsiveness may constitute a genetic platform for the disease. By contrast, the overexpression of COX, and the resulting overproduction of endoperoxides probably reflect an adjustment to the chronic hypertensive process, resulting in premature aging of the endothelial cells. This interpretation is reinforced by the observations that endothelium-dependent contractions appear also in arteries of aging normotensive animals (Koga et al., 1989; Mombouli \& Vanhoutte, 1993; Fujii et al., 1999; Imaoka et al., 1999; Heymes et al., 2000). Likewise, in porcine coronary arteries lined with senescent, regenerated endothelial cells, EDCF-mediated responses are observed (Shimokawa \& Vanhoutte, 1989). Thus, EDCF contributes to the endothelial dysfunction, which expresses itself particularly by a reduced protective role against platelet aggregation (Ito et al., 1991; Miyamoto et al., 1999). This eventually will set in motion the atherosclerotic process, a major complication of both hypertension and diabetes (e.g. Vanhoutte, 1997). This conclusion is strengthened by the demonstration that in the animal, the TP-receptor antagonist S18886 inhibits the atherosclerotic process (Cayatte et al., 1999; Cohen et al., 2001; Cheng et al., 2002), as well as by the observation that in the rat chronic treatment with aspirin can prevent the induction of hypertension (El Midaoui et al., 2002). 


\section{Human studies}

\section{COX-dependent vasoconstrictions}

In healthy subjects, the infusion of $\mathrm{ACh}$ into the brachial artery causes a dose-dependent increase in forearm blood flow (measured by strain-gauge venous plethysmography). This vasodilatation is likely to be NO-dependent since it can be blocked by an inhibitor of NO synthase (Taddei et al., 1993). By contrast, the response to $\mathrm{ACh}$ is unaltered after the intrabrachial infusion of indomethacin, indicating that products of COX do not play a major role in endotheliumdependent responses under normal conditions (Taddei et al., 1998). In essential hypertensive, the vasodilatation to $\mathrm{ACh}$ is blunted, as well as resistant to inhibition of NO synthase (Dohi et al., 1990). In those patients, indomethacin increases, and indeed almost normalizes, the vasodilator response to the muscarinic agonist (Figure 17; Taddei et al., 1998). These findings demonstrate that in essential human hypertension, vasoconstrictor products of $\mathrm{COX}$ are mainly responsible for the abnormal reaction to endothelium-dependent vasodilators. The parallelism with the experiments in hypertensive animals is striking, and warrants the conclusion that EDCF must play a key role in the resulting endothelial dysfunction. This may not be the case in all forms of high blood pressure. Thus, in patients with hypertension secondary to primary aldosteronism or to renovascular disease, who are also characterized by curtailed endothelium-dependent vasodilatations (Taddei et al., 1998), inhibition of COX does not improve the response to ACh, suggesting that EDCF plays a minimal role in the endothelial dysfunction of secondary hypertension in people. Again, these results agree well with those obtained in animals with salt-dependent hypertension (Lüscher et al., 1987), comforting the interpretation that involvement of EDCF is not a mere consequence of the chronic increase in arterial blood pressure, but requires a genetic background facilitating the occurrence of premature aging of the blood vessel wall faced with the essential (spontaneous) hypertensive process.

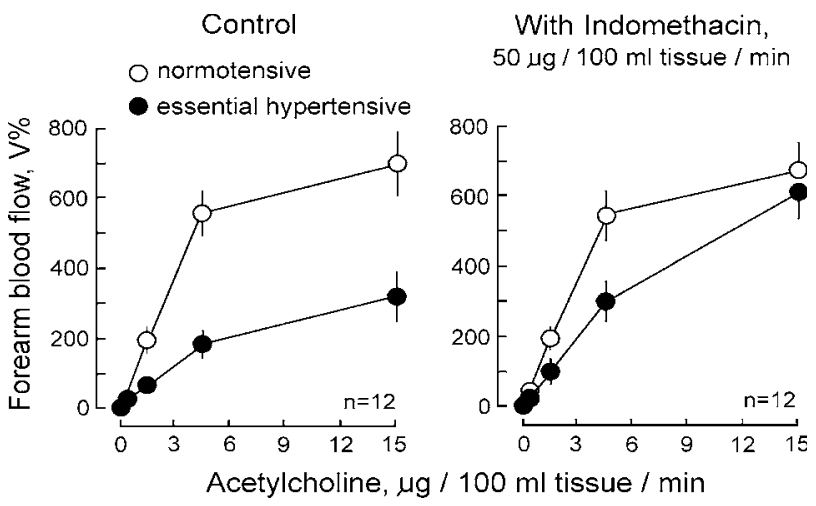

Figure 17 Line graphs show increase in forearm blood flow (FBF) induced by intra-arterial administration of ACh under control condition (saline infusion) (left panel) and in the presence of intraarterial administration of indomethacin (right panel) in normotensive subjects (open symbols; $n=12$ ) and essential hypertensive patients (close symbols; $n=12$ ). Data are shown as mean \pm s.e.m. and expressed as percent increase above basal (data from Taddei et al., 1997a; by permission of the AHA).

\section{Effect of age}

Aging in the human is characterized by a progressive endothelial impairment that is evidenced by reduced dilatations in response to endothelium-dependent vasodilators, demonstrated both in conduit arteries and at the microcirculatory level, in the forearm as well as in the coronary circulation (Zeiher et al., 1993; Taddei et al., 1995; 1997a,b). In normotensive subjects up to the age of 60 years old, the main mechanism responsible for the progressive endothelial dysfunction is a primary defect in the L-arginine-NO pathway, without evidence of a substantial contribution of EDCF (Figure 18; Taddei et al., 1997b). However, in subjects older than 60 years, the infusion of indomethacin potentiates the vasodilatation to $\mathrm{ACh}$, suggesting that EDCF kicks in (Figure 18; Taddei et al., 1997b). The production of COXdependent factors is associated with a further and parallel impairment in the L-arginine-NO pathway (Figure 18; Taddei et al., 1997b). In essential hypertensive patients, on the other hand, the contribution of COX-derived vasoconstrictor substances (most likely EDCF), is already detectable in the age group of 31-45 years, and augments in parallel with increasing age (Figure 18; Taddei et al., 1997a, b). These finding certainly support the conclusion that the production of COX-derived EDCF is a characteristic of the aging blood vessel wall, with essential hypertension merely causing an earlier onset and an acceleration of this endothelial alteration.

\section{Involvement of oxygen-derived free radicals}

In essential hypertensive patients, indomethacin not only potentiates the vasodilatation to $\mathrm{ACh}$, but also restores the inhibitory effect of L-NMMA (an inhibitor of NO synthase) on that response, indicating that the activity of COX generates substances that reduce the availability of NO (Taddei et al., 2001). These substances probably are oxygen-derived free

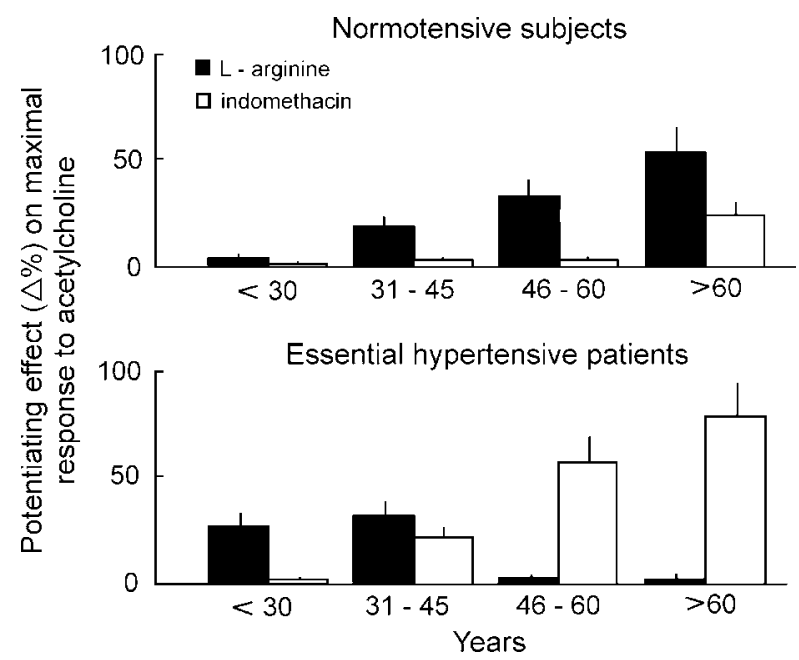

Figure 18 Bars show the potentiating effect on maximal response to ACh exerted by intrabrachial administration of $\mathrm{L}$-arginine $(1 \mu \mathrm{mol}$

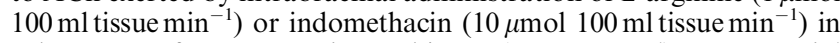
subgroups of normotensive subjects (upper panel) or essential hypertensive patients (lower panel) characterized by four different age profile. Data are shown as mean \pm s.e.m. and expressed as percent increase (data from Taddei et al., 1995; by permission of the AHA). 
radicals since the intrabrachial infusion of the vitamin $\mathrm{C}$ (which scavenges these radicals) has a similar effect as indomethacin on the responses to $\mathrm{ACh}$ and inhibition of NO synthase in essential hypertensives older than 30 years of age (Dohi et al., 1990). The simultaneous administration of indomethacin and vitamin $\mathrm{C}$ has no additive effect, and causes no further improvement in endothelium-dependent vasodilatation (Dohi et al., 1990). Again, similarly to the results obtained with indomethacin, vitamin $\mathrm{C}$ improves the vasodilator response to $\mathrm{ACh}$ also in normotensive subjects older than 60 years of age (Taddei et al., 2001). Taken in conjunction, these studies indicate that in the ageing and essential hypertensive human, oxygen-derived free radicals produced by COX contribute to EDCF-mediated responses. Similar COX-dependent vasoconstrictions involving oxygen-derived free radicals may explain, at least in part, the blunted dilator response to ACh observed in estrogen-deprivation or in the course of congestive heart failure (e.g. Taddei et al., 1996; Butler et al., 2000; Virdis et al., 2000; Vita \& Keaney, 2002; Taddei \& Salvetti, 2002)

\section{Role in vascular disease}

In humans, endothelial dysfunction accompanies all cardiovascular risk factors and presumably plays a causal role in the occurrence of cardiovascular events. The main alteration ascribable to endothelial dysfunction is a reduced (or absent) availability of $\mathrm{NO}$, essentially as a consequence of increased oxidative stress. Indeed, in addition to its relaxing activity, NO inhibits platelet aggregation, proliferation and migration vascular smooth cells, expression of adhesion molecules (and thus the adhesion of platelets and white cells), and production of endothelin-1, thus protecting the blood vessel wall from the initial events leading to thrombosis and atherosclerosis (e.g. Vanhoutte, 1997). Hence, in the coronary and carotid arteries, areas covered with dysfunctional endothelium become prone to develop atherosclerotic lesions, and endothelial dysfunction

\section{References}

AUCH-SCHWELK, W., KATUSIC, Z.S. \& VANHOUTTE, P.M. (1989). Contractions to oxygen-derived free radicals are augmented in aorta of the spontaneously hypertensive rat. Hypertension, 13, $859-864$.

AUCH-SCHWELK, W., KATUSIC, Z.S. \& VANHOUTTE, P.M. (1990). Thromboxane $\mathrm{A}_{2}$ receptor antagonists inhibit endothelium-dependent contractions. Hypertension, 15, 699-703.

AUCH-SCHWELK, W., KATUSIC, Z.S. \& VANHOUTTE, P.M. (1992). Nitric oxide inactivates endothelium-derived contracting factor in the rat aorta. Hypertension, 19, 442-445.

BOULANGER, C.M., MORRISON, K.J. \& VANHOUTTE, P.M. (1994). $\mathrm{M}_{3}$-muscarinic receptors mediate both endotheliumdependent contraction and relaxation to acetylcholine in the aorta of the spontaneously hypertensive rat. Br. J. Pharmacol., 112, 519-524.

BUTLER, R., MORRIS, A.D., BELCH, J.J.F., HILL, A. \& STRUTHERS, A.D. (2000). Allopurinol normalizes endothelial dysfunction in type 2 diabetics with mild hypertension. Hypertension, 35, 746-751.

CAI, H. \& HARRISON, D.G. (2000). Endothelial dysfunction in cardiovascular diseases. Circ. Res., 87, 840-844

CAYATTE, A.J., DU, Y., OLIVER-KRASINSKI, J., LAVIELLE, G., VERBEUREN, T.J. \& COHEN, R.A. (1999). The thromboxane A2 receptor antagonist, $\mathrm{S} 18886$, but not aspirin inhibits atherogenesis in apolipoprotein E deficient mice. Arteriosler. Thromb. Vasc. Biol., 20, 1724-1728. becomes an independent predictor of cardiovascular events (Vita \& Keaney, 2002). Both the animal and human data at hand strongly suggest that the production of COX-dependent EDCF is one of the principal mechanisms leading to an impaired availability of $\mathrm{NO}$, at least in aging or essential (spontaneous) hypertension. Therefore, endothelial dysfunction accompanied by the production of EDCF must play a key role in the progression of cardiovascular disease. Since inhibition of the production or the action of EDCF obviously restores the availability of NO, drugs aiming at such inhibition could represent an addition for the therapy, the complications of cardiovascular disease and possibly the prevention of cardiovascular events. This prediction is supported by the blood pressure lowering effect of chronic treatment with aspirin in otherwise untreated hypertensive patients (Hermida et al., 2003).

\section{Conclusion}

Endothelial cells can release vasoconstrictor metabolites of arachidonic acid, which have been termed EDCF as they can contribute to moment-to-moment changes in contractile activity of the underlying vascular smooth muscle cells. In the animal, EDCF-mediated responses are exacerbated by aging, spontaneous hypertension and diabetes, and probably reflect the premature aging of the blood vessel wall subjected to an exaggerated oxidative stress. The limited information available in the human confirms that EDCF-mediated responses contribute to the blunting of endothelium-dependent vasodilatations in aged subjects and essential hypertensive patients. Since EDCF causes vasoconstriction by activation of the TP-receptors on the vascular smooth muscle cells, selective antagonists at these receptors prevent endothelium-dependent contractions, and reverse the endothelial dysfunction in hypertension and diabetes.
CHANG, K.C., CHUNG, S.Y., CHONG, W.S., SUH, J.S., KIM, S.H., NOH, H.K., SEONG, B.W., KO, H.J. \& CHUN, K.W. (1993). Possible superoxide radical-induced alteration of vascular reactivity in aortas from streptozotocin-treated rats. J. Pharmacol. Exp. Ther. 266, 992-1000.

CHENG, Y., AUSTIN, S.C., ROCCA, B., KOLlER, B.H., COFFMAN, T.M., GROSSER, T., LAWSON, J.A. \& FITZGERALD, G.A. (2002). Role of prostacyclin in the cardiovascular response to thromboxane A2. Science, 296, 539-541.

COHEN, R.A., XU, S., MAITLAND, K., CAYATTE, A.J., LAVIELLE, G. \& VERBEUREN, T.J. (2001). The TP-receptor antagonist, S18886, prevents the enhancement of atherogenesis by diabetes mellitus in apolipoprotein E deficient mice. Circulation, 104, II118.

COSENTINO, F., HISHIKAWA, K., KATUSIC, Z.S. \& LÜSCHER, T.F. (1996). High glucose increases nitric oxide synthase expression and superoxide anion generation in human aortic endothelial cells. Circulation, 94 (suppl I), I1093.

COSENTINO, F., SILL, J.C. \& KATUSIC, Z.S. (1994). Role of superoxide anions in the mediation of endothelium-dependent contractions. Hypertension, 23, 229-235.

DANTAS, A.P.V., SCIVOLETTO, R., FORTES, Z.B., NIGRO, D. \& CARVALHO, M.H.C. (1999). Influence of female sex hormones on endothelium-derived vasoconstrictor prostanoid generation in microvessels of spontaneously hypertensive rats. Hypertension, 34, 914-919. 
DAVIDGE, S.T. \& ZHANG, Y.L. (1998). Estrogen replacement suppresses a prostaglandin $\mathrm{H}$ synthase-dependent vasoconstrictor in rat mesenteric arteries. Circ. Res., 83, 388-395.

DE MEY, J.G. \& VANHOUTTE, P.M. (1982). Heterogeneous behavior of the canine arterial and venous wall: importance of the endothelium. Circ. Res., 51, 439-447.

DOHI, Y., THIEL, M.A., BUHLER, F.R. \& LÜSCHER, T.F. (1990). Activation of endothelial L-arginine pathway in resistance arteries. Effect of age and hypertension. Hypertension, 16, 170-179.

EL MIDAOUI, A., WU, R. \& DE CHAMPLAIN, J. (2002). Prevention of hypertension, hyperglycemia and vascular oxidative stress by aspirin treatment in chronically glucose-fed rats. J. Hypertens., 20, 1407-1412.

FUJII, K., ONAKA, U., ABE, I. \& FUJISHIMA, M. (1999). Eicosanoids and membrane properties in arteries of aged spontaneously hypertensive rats. J. Hypertens., 17, 75-80.

FURCHGOTT, R.F. \& VANHOUTTE, P.M. (1989). Endotheliumderived relaxing and contracting factors. FASEB J., 3, 2007-2017.

FURCHGOTT, R.F. \& ZAWADZKI, J.V. (1980). The obligatory role of endothelial cells in the relaxation of arterial smooth muscle by acetylcholine. Nature, 299, 373-376.

GE, T., HUGHeS, H., JUNQUERO, D.C., WU, K.K., VANHOUTTE, P.M. \& BOULANGER, C.M. (1995). Endothelium-dependent contractions are associated with both augmented expression of prostaglandin $\mathrm{H}$ synthase-1 and hypersensitivity to prostaglandin H2 in the SHR aorta. Circ. Res., 76, 1003-1010.

GE, T., VANHOUTTE, P.M. \& BOULANGER, C.M. (1999). Increased response to prostaglandin $\mathrm{H}_{2}$ precedes changes in PGFsynthase 1 expression in the SHR aorta. Acta Pharmacol. Sinica, 20, 1087-1092.

GRAIER, W.F., POSCH, K., FLEISCHHACKER, E., WASCHER, T.C. \& KOSTNER, G.M. (1999). Increased superoxide anion formation in endothelial cells during hyperglycemia: an adaptive response or initial step of vascular dysfunction? Diabetes Res. Clin. Pract., 45, $153-160$.

GRÄSER, T. \& VANHOUTTE, P.M. (1991). Hypoxic contraction of canine coronary arteries: role of endothelium and cGMP. Am. J. Physiol., 261, H1769-H1777.

HERMIDA, R.C., AYALA, D.E., CALVO, C., LOPEZ, J.E., FERNANDEZ, J.R., MOJON, A., DOMINGUEZ, M.J. \& COVELO, M. (2003). Administration time-dependent effects of aspirin on blood pressure in untreated hypertensive patients. Hypertension, 41, 1259-1267.

HEYMES, C., HABIB, A., YANG, D., MATHIEU, E., MAROTTE, F., SAMUEL, J.L. \& BOULANGER, C.M. (2000). Cyclo-oxygenase-1 and -2 contribution to endothelial dysfunction in ageing. $\mathrm{Br} . J$. Pharmacol., 131, 804-810.

IMAOKA, Y., OSANAI, T., KAMADA, T., MIO, Y., SATOH, K. \& OKUMURA, K. (1999). Nitric oxide-dependent vasodilator mechanism is not impaired by hypertension but is diminished with aging in the rat aorta. J. Cardiovasc. Pharmacol., 33, 756-761.

ITO, T., KATO, T., IWAMA, Y., MURAMATSU, M., SHIMIZU, K., ASANO, H., OKUMURA, K., HASHIMOTO, H. \& SATAKE, T. (1991). Prostaglandin H2 as an endothelium-derived contracting factor and its interaction with nitric oxide. J. Hypertens., 9, 729-736.

IWAMA, Y., KATO, T., MURAMATSU, M., ASANO, H., SHIMIZU, K., TOKI, Y., MIYAZAKI, Y., OKUMURA, K., HASHIMOTO, H., ITO, T. \& SATAKE, T. (1992). Correlation with blood pressure of the acetylcholine-induced endothelium-derived contracting factor in the rat aorta. Hypertension, 19, 326-332.

JAMESON, M., DAI, F.X., LÜSCHER, T., SKOPEC, J. \& DIEDERICH, A. (1993). Endothelium-derived contracting factors in resistance arteries of young spontaneously hypertensive rats before development of overt hypertension. Hypertension, 21, 280-288

KATUSIC, Z., SHEPHERD, J.T. \& VANHOUTTE, P.M. (1987). Endothelium-dependent contraction to stretch in canine basilar arteries. Am. J. Physiol., 21, H671-H673.

KATUSIC, Z.M. \& VANHOUTTE, P.M. (1989a). Endothelium-dependent contractions to $N^{\mathrm{G}}$-monomethyl-L-arginine in canine basilar artery. In: Rubanyi GM, Vanhoutte PM (eds). Endothelium-Derived Relaxing Factors. Basel: Karger.

KATUSIC, Z.S. (1996). Superoxide anion and endothelial regulation of arterial tone. Free Radicals Biol. Med., 20, 443-448.
KATUSIC, Z.S., SHEPHERD, J.T. \& VANHOUTTE, P.M. (1988). Endothelium-dependent contractions to calcium ionophore A23187, arachidonic acid and acetylcholine in canine basilar arteries. Stroke, 19, 476-479.

KATUSIC, Z.S. \& VANHOUTTE, P.M. (1989b). Superoxide anion is an endothelium-derived contracting factor. Am. J. Physiol., 257, H33-H37.

KEEGAN, A., WALBANK, H., COTTER, M.A. \& CAMERON, N.E. (1995). Chronic vitamin E treatment prevents defective endothelium-dependent relaxation in diabetic rat aorta. Diabetologia, $\mathbf{3 8}$, $1475-1478$.

KOGA, T., TAKATA, Y., KOBAYASHI, K., TAKISHITA, S., YAMASHITA, Y. \& FUJISHIMA, M. (1989). Age and hypertension promote endothelium-dependent contraction to acetylcholine in the aorta of the rat. Hypertension, 14, 542-548.

KOJDA, G. \& HARRISON, D. (1999). Interactions between NO and reactive oxygen species: pathophysiological importance in atherosclerosis, hypertension, diabetes and heart failure. Cardiovasc. Res. 43, 562-571

LIN, K.Y., ITO, A., ASAGAMI, T., TSAO, P.S., ADIMOOLAM, S. KIMOTO, M., TSUJI, H., REAVEN, G.M. \& COOKE, J.P. (2002). Impaired nitric oxide synthase pathway in diabetes mellitus. Role of asymmetric dimethylarginine and dimethylarginine dimethylaminohydrolase. Circulation, 106, 987-992.

LÜSCHER, T.F., RAIJ, L. \& VANHOUTTE, P.M. (1987). Endotheliumdependent vascular responses in normotensive and hypertensive Dahl-rats. Hypertension, 9, 157-163.

LÜSCHER, T.F. \& VANHOUTTE, P.M. (1986a). Endothelium-dependent contractions to acetylcholine in the aorta of the spontaneously hypertensive rat. Hypertension, 8, 344-348.

LÜSCHER, T.F. \& VANHOUTTE, P.M. (1986b). Endothelium-dependent responses to platelets and serotonin in spontaneously hypertensive rats. Hypertension, 8, II55-II60.

LÜSCHER, T.F. \& VANHOUTTE, P.M. (1990). The Endothelium: Modulator of Cardiovascular Function. Boca Raton, FL: CRC Press, pp. 1-215.

MAYHAN, W.G. \& PATEL, K.P. (1998). Treatment with dimethylthiourea prevents impaired dilatation of the basilar artery during diabetes mellitus. Am. J. Physiol. Heart Circ. Physiol., 43, H1895-H1901.

MCINTYRE, M., BOHR, D.F. \& DOMINICZAK, A.F. (1999). Endothelial function in hypertension. The role of superoxide anion. Hypertension, 34, 539-545.

MILLER, V.M. \& VANHOUTTE, P.M. (1985). Endothelium-dependent contractions to arachidonic acid are mediated by products of cyclo-oxygenase in canine veins. Am. J. Physiol., 248, $\mathrm{H} 432-\mathrm{H} 437$

MIYAMOTO, A., ISHIGURO, S. \& NISHIO, A. (1999). Stimulation of bradykinin $\mathrm{B}_{2}$-receptors on endothelial cells induces relaxation and contraction in porcine basilar artery in vivo. Br. J. Pharmacol., 128 , $241-247$

MIYATA, N., YAMAURA, H., TSUCHIDA, K., OKUYAMA, S. OTOMO, S., KAMATA, K. \& KASUYA, Y. (1993). Impairment of endothelium-dependent relaxation of superior mesenteric artery in genetically diabetic WBN/Kob rats. Can. J. Physiol. Pharmacol., 71, 297-300.

MOMBOULI, J.V. \& VANHOUTTE, P.M. (1993). Purinergic endothelium-dependent and independent contractions in rat aorta. Hypertension, 22, 577-583.

NASSAR, T., KADERY, B., LOTAN, C., DA'AS, N., KLEINMAN, Y. \& HAJ-YEHIA, A. (2002). Effects of the superoxide dismutasemimetic compound tempol on endothelial dysfunction in streptozotocin-induced diabetic rats. Eur. J. Pharmacol., 436, $111-118$.

PEARSON, P.J., LIN, P.J., SCHAFF, H.V. \& VANHOUTTE, P.M. (1996). Augmented endothelium-dependent constriction to hypoxia early and late following reperfusion of the canine coronary artery. Clin Exp. Pharmacol. Physiol., 23, 634-641.

PFISTER, S.L. \& CAMPBELL, W.B. (1996). Role of endotheliumderived metabolites of arachidonic acid in enhanced pulmonary artery contractions in female rabbits. Hypertension, 27, 43-48.

PIEPER, G.M. (1999). Enhanced, unaltered and impaired nitric oxidemediated endothelium-dependent relaxation in experimental diabetes mellitus: importance of disease duration. Diabetologia, 42, 204-213. 
RAPOPORT, R.M. \& WILLIAMS, S.P. (1996). Role of prostaglandins in acetylcholine-induced contraction of the aorta from spontaneously hypertensive and Wistar-Kyoto rats. Hypertension, 28, 64-75.

REES, D.D., PALMER, R.M.J. \& MONCADA, S. (1989). The role of endothelium-derived nitric oxide in the regulation of blood pressure. Proc. Natl. Acad. Sci. U.S.A., 86, 3375-3378.

RODRIGUEZ-MARTINEZ, M.A., CARCIA-COHEN, E.C., BAENA, A.B., GONZAleZ, R., SAlAICES, M. \& MARIN, J. (1998). Contractile responses elicited by hydrogen peroxide in aorta from normotensive and hypertensive rats. Endothelial modulation and mechanism involved. Br. J. Pharmacol., 125, 1329-1335.

RUBANYI, G.M. \& VANHOUTTE, P.M. (1986). Superoxide anions and hyperoxia inactivate endothelium-derived relaxing factor(s). Am. $J$. Physiol., 50, H822-H827.

SAIFEDDINE, M., ROY, S.S., AL-ANI, B., TRIGGLE, C.R. \& HOLLENBERG, M.D. (1998). Endothelium-dependent contractile actions of proteinase-activated receptor-2-activating peptides in human umbilical vein: release of a contracting factor via a novel receptor. $B r . J$. Pharmacol., 125, 1445-1454.

SCHNACKENBERG, C.G. \& WILCOX, C.S. (2001). The SOD mimetic tempol restores vasodilation in afferent arterioles of experimental diabetes. Kidney Int., 59, 1859-1864.

SHIMOKAWA, H. \& VANHOUTTE, P.M. (1989). Impaired endothelium-dependent relaxation to aggregating platelets and related vasoactive substances in porcine coronary arteries in hypercholesterolemia and in atherosclerosis. Circ. Res., 64, 900-914.

SHINOZAKI, K., KASHIWAGI, A., NISHIO, Y., OKAMURA, T., YOSHIDA, Y., MASADA, M., TODA, N. \& KIKKAWA, R. (1999). Abnormal biopterin metabolism is a major cause of impaired endothelium-dependent relaxation through nitric oxide $/ \mathrm{O}_{2}$-imbalance in insulin-resistant rat aorta. Diabetes, $\mathbf{4 8}$, $2437-2445$.

STREEFKERK, J.O., PFAFFENDORF, M. \& VAN ZWIETEN, P.A. (2003). Endothelium-dependent, vasopressin-induced contractions in rabbit renal arteries. J. Cardiovasc. Pharmacol., 42, 703-709.

TADDEI, S. \& SALVETTI, A. (2002). Endotelial dysfunction in essential hypertension: clinical implications. J. Hypertens., $\mathbf{2 0}, 1$.

TADDEI, S. \& VANHOUTTE, P.M. (1993). Role of endothelium in endothelin-evoked contractions in the rat aorta. Hypertension, 21, $9-15$.

TADDEI, S., VIRDIS, A., GHIADONI, L., MAGAGNA, A. \& SALVETTI, A. (1997a). Cyclooxygenase inhibition restores nitric oxide activity in essential hypertension. Hypertension, 29, 274-279.

TADDEI, S., VIRDIS, A., GHIADONI, L., MAGAGNA, A. \& SALVETTI, A. (1998). Vitamin C improves endothelium-dependent vasodilation by restoring nitric oxide activity in essential hypertension. Circulation, 97, 2222-2229.

TADDEI, S., VIRDIS, A., GHIADONI, L., MATTEI, P., SUDANO, I., BERNINI, G., PINTO, S. \& SALVETTI, A. (1996). Menopause is associated with endothelial dysfunction in women. Hypertension, 28, 576-582.

TADDEI, S., VIRDIS, A., GHIADONI, L., SALVETTI, G., BERNINI, G., MAGAGNA, A. \& SALVETTI, A. (2001). Age-related reduction of NO availability and oxidative stress in humans. Hypertension, $\mathbf{3 8}$, 274-279.

TADDEI, S., VIRDIS, A., MATTEI, P., GHIADONI, L., GENNARI, A., FASOLO, C.B., SUDANO, I. \& SALVETTI, A. (1995). Aging and endothelial function in normotensive subjects and patients with essential hypertension. Circulation, 91, 1981-1987.

TADDEI, S., VIRDis, A., MATTEI, P. \& SAlVetTi, A. (1993). Vasodilation to acetylcholine in primary and secondary forms of human hypertension. Hypertension, 21, 929-933.

TADDEI, S., VIRDIS, A., MATTEI, P., GHIADONI, L., BASILEFASOLO, C., SUDANO, I. \& SALVETTI, A. (1997b). Hypertension causes premature aging of endothelial function in humans. Hypertension, 29, 736-743.

TAYLOR, P.D., OON, B.B., THOMAS, C.R. \& POSTON, L. (1994). Prevention by insulin treatment of endothelial dysfunction but not enhanced noradrenaline-induced contractility in mesenteric resistance arteries from streptozotocin-induced diabetic rats. $\mathrm{Br} . J$. Pharmacol., 111, 35-41.
TESFAMARIAM, B., BROWN, M.L., DEYKIN, D. \& COHEN, R.A. (1990). Elevated glucose promotes generation of endotheliumderived vasoconstrictor prostanoids in rabbit aorta. J. Clin. Invest. 85, 929-932.

TESFAMARIAM, B. \& COHEN, R.A. (1992). Free radicals mediate endothelial cell dysfunction caused by elevated glucose. Am. J. Physiol., 263, H321-H326.

TESFAMARIAM, B., JAKUBOWSKI, J.A. \& COHEN, R.A. (1989) Contraction of diabetic rabbit aorta caused by endothelium-derived PGH2-TxA2. Am. J. Physiol., 257, H1327-H1333.

TRAN, C.T., LEIPER, J.M. \& VALLANCE, P. (2003). The DDAH ADMA/NOS pathway. Atheroscler. Suppl., 4, 33-40.

VALLANCE, P., LEONE, A., CALVER, A., COLLIER, J. \& MONCADA, S. (1992). Accumulation of an endogenous inhibitor of nitric oxide synthesis in chronic renal failure. Lancet, 339, 572-575.

VANHOUTTE, P.M. (1997). Endothelial dysfunction and atherosclerosis. Eur. Heart J., 18, E19-E29.

VANHOUTTE, P.M. \& BOULANGER, C.M. (1995). Endotheliumdependent responses in hypertension. Hypertens. Res., 18, 87-98.

VANHOUTTE, P.M. \& KATUSIC, Z.S. (1988). Endothelium-derived contracting factor: endothelin and/or superoxide anion? Trends Pharmacol. Sci., 9, 229-230.

VANHOUTTE, P.M., LÜSCHER, T.F. \& GRÄSER, T. (1991). Endothelium-dependent contractions. Blood Vessels, 28, 74-83.

VANHOUTTE, P.M. (1993). The other endothelium-derived vasoactive factors. Circulation, 87 (Suppl V), V9-V17.

VANHOUTTE, P.M. (1996). Endothelial dysfunction in hypertension. J. Hypertens., 14, S83-S93.

VANHOUTTE, P.M. (2000). Say no to ET. J. Auton. Nerv. System, $\mathbf{8 1}$ 271-277.

VANHOUTTE, P.M. (2001). Endothelium-derived free radicals: for worse and for better. J. Clin. Invest., 107, 23-25.

VIRDIS, A., GHIADONI, L., PINTO, S., LOMBARDO, M., PETRAGLIA, F., GENNAZZANI, A., BURALLI, S., TADDEI, S. \& SALVETTI, A. (2000). Mechanisms responsible for endothelial dysfunction associated with acute estrogen deprivation in normotensive women. Circulation, 101, 2258-2263.

VITA, J.A. \& KEANEY JR, J.F. (2002). Endothelial function: a barometer for cardiovascular risk? Circulation, 106, 640-642.

YANG, D., FÉLÉTOU, M., BOULANGER, C.M., WU, H.F., LEVENS, N., ZHANG, J.N. \& VANHOUTTE, P.M. (2002). Oxygen-derived free radicals mediate endothelium-dependent contractions to acetylcholine in aortas from spontaneously hypertenive rats. $\mathrm{Br} . \mathrm{J}$. Pharmacol., 136, 104-110.

YANG, D., FÉLÉTOU, M., LEVENS, N., ZHANG, J.N. \& VANHOUTTE, P.M. (2003a). A diffusible substance(s) mediates endotheliumdependent contractions in the aorta of SHR. Hypertension, 41, $143-148$.

YANG, D., LEVENS, N., ZHANG, J.N., VANHOUTTE, P.M. \& FÉLÉTOU, M. (2003b). Specific potentiation of endotheliumdependent contractions in SHR by tetrahydrobiopterin. Hypertension, 41, 136-142.

ZANETTI, M., SATO, J., KATUSIC, Z.S. \& O’BRIEN, T. (2001). Gene transfer of superoxide dismutase isoforms reverses endothelial dysfunction in diabetic rabbit aorta. Am. J. Physiol. Heart Circ. Physiol., 280, H2516-H2523.

ZEIHER, A.M., DREXLER, H., SAURBIER, B. \& JUST, H. (1993). Endothelium-mediated coronary blood flow modulation in humans. Effects of age, atherosclerosis, hypercholesterolemia, and hypertension. J. Clin. Invest., 92, 652-662.

ZHOU, M.S., KOSAKA, H., TIAN, R.X., ABE, Y., CHEN, Q.H., YONEYAMA, H., YAMAMOTO, A. \& ZHANG, L. (2001). L-Arginine improves endothelial function in renal artery of hypersensitive Dahl rats. J. Hypertens., 19, 421-429.

ZHU, M.S., NISHIDA, Y., CHEN, Q.H. \& KOSAKA, H. (1999). Endothelium-derived contracting factor in carotid artery of hypertensive Dahl rats. Hypertension, 34, 39-43.

(Received August 6, 2004 Revised September 13, 2004 Accepted October 5, 2004) 